\title{
The Argentine Military and the "Antisubversivo" Genocide: The School of Americas' Contribution to the French Counterinsurgency Model
}

Khatchik DerGhougassian

UNLa, Argentina

\section{Leiza Brumat}

EUI, Italy

\begin{abstract}
The article analyzes role of the United States during the 1976-1983 military dictatorship and their genocidal counterinsurgency war in Argentina. We argue that Washington's policy evolved from the initial loose support of the Ford administration to what we call "the Carter exception" in 1977-79 when the violation of Human Rights were denounced and concrete measures taken to put pressure on the military to end their repressive campaign. Human Rights, however, lost their importance on Washington's foreign policy agenda with the Soviet invasion of Afghanistan in 1979 and the end of the Détente. The Argentine military briefly recuperated US support with Ronald Reagan in 1981 to soon lose it with the Malvinas War. Argentina's defeat turned the page of the US support to military dictatorships in Latin America and marked the debut of "democracy promotion."
\end{abstract}

Keywords: Proceso, dirty war, human rights, Argentine military, French School, the School of the Americas, Carter 


\section{Introduction: Framing the US. Role during the Proceso}

When an Argentine military junta seized the power on March 24, 1976 and implemented its "plan antisubversivo," a supposedly counterinsurgency plan to end the political violence in the country, Henry Kissinger, the then United States' Secretary of State of the Gerald Ford Administration, warned his Argentine colleague that the critiques for the violation of human rights would increment and it was convenient to end the "operations" before January of 1977 when Jimmy Carter, the Democratic candidate and winner of the presidential elections, would assume the power in the White House. Kissinger, an active promoter of the Augusto Pinochet's 1973 coup in Chile, faced harsh criticism in the Congress and, according to declassified documents, his collaborators convinced him not to repeat the history in the Argentine case because "there will be a lot of blood" and very soon the Junta will be "much less popular in the press."

Indeed, while the Argentine military dismissed the advice and proceeded with a historically unprecedented brutal repression in the country for the next six years when they withheld the power, Washington's "distant support" position became increasingly critical. The Carter administration's Assistant Secretary of State for Human Rights and Humanitarian Affairs, Patricia Derian, visited Argentina three times and warned the military about forthcoming sanctions, which soon became effective with the suspension of military aid, denial for demands for credit lines and UN votes classifying Argentina along with Cuba and the Soviet Union as a country where Human Rights were violated systematically and, thus, harming its international reputation. The US criticism and, in fact, 
the international campaign denouncing the Junta had little if any effect on the Proceso. ${ }^{2}$ The 1984 report of the National Commission on the Disappearance of Persons (CONADEP in its Spanish initials) created on December 15, 1983 by President Raúl Alfonsín five days after assuming power to investigate the crimes of the dictatorship, identified preliminary 8961persons who became "desaparecidos,"3 380 clandestine centers of detention and 1500 names of persons suspected of being part of criminal actions. ${ }^{4}$ These darkest pages of the Argentine history were labeled as a "dirty war," though the repression was nothing less than the exercise of state terrorism, ${ }^{6}$ which, in turn, was much more than the mere "disciplining" of the society and was the necessary mean to begin implementing neoliberal policies. As Ruth Blakeley explains, "[n]eoliberalism involves dismantling the apparatus of mercantilist protection operated at state level, the opening of previously closed economies to the forces of economic competition, macroeconomic discipline, globalized rather than national economics, and foreign direct investment. At the heart of neoliberalism as an abstract principle is the notion that markets should solve all economic problems but, in practice, this has not meant dispensing with the state. Indeed, neoliberalism requires the state."7

The neoliberal project was not invented in Latin America, or what is labeled as the "global South." It was designed in US and European universities and Think-Tanks and needed the leadership of "experts," such as the Chicago Boys in Chile and the economist Martínez de Hoz, coup leader Videla's Minister of Economy, in Argentina, for its implementation; hence, the terrorist state was also a civil-military dictatorship with a sort of "labor division" with the military in charge of the repression and the civilian experimenting the neoliberal receipts. ${ }^{8}$ True, the neoliberal project was not the military's prime concern, 
and, thus, the Proceso was ideologically oriented more in the sense of a "mission" of defending Western/Christian "values" against leftist/populist subversion; this sense of "mission" was also the core argument of the pro-US/Western alignment of the Cold War in the 1960s. ${ }^{9}$ Yet, the very fact of the civilian involvement in military governments for the sake of the implementation of the neoliberal project, in fact the first experimental attempts to what will become the dominant paradigm with the Reagan-Thatcher "Conservative Revolution" in the 1980s and the global spread of the free-market in the 1990s, reflects Blakeley's argument about "coercion, including state terrorism, dominat[ing] the practices of early European imperialisms, as well as early American imperialism, and [being] a defining feature of the US efforts to secure access to and control of resources and markets in the South throughout the Cold War period." ${ }^{\prime 10}$ It is worth, in this sense, considering that the Détente never reached Latin America, quite the opposite it marked the bloodiest historical period for South Americans ${ }^{11} \ldots$

Nevertheless, while the US involvement in Chile with the 1973 Pinochet's coup is hardly controversial and the Nixon administration's role in preparing, supporting and promoting it is well documented, made public and has even led to a judicial process against Henry Kissinger, Washington's relation with the Proceso is more complex. The CONADEP report includes a whole chapter highlighting the ideological backing of the dictatorship and the constant reference the military made to the US-Argentina alliance since the 1960s. ${ }^{12}$ It is well known that high ranking Argentine officers, including Generals Viola and Galtieri, were graduated from the School of the Americas. ${ }^{13}$ However, the influence of the so-called French School on the Argentine military was not only prior to the School of the Americas but arguably also deeper. ${ }^{14}$ 
Qualifying the state terrorism in Argentina as "genocide" has always been problematic. ${ }^{15}$ Some experts prefer the use of the concept of "politicide," 16 others insist on “state terrorism.” Yet, since the Spanish judge Baltazar Garzón's first attempt to use the term "genocide" in his accusation against the Argentine naval officer Adolfo Scilingo in 2005, which Spain's Supreme Court rejected, and, later, an Argentine court's sentence against the police chief of Buenos Aires, Miguel Etchecolatz, in 2006 accused of committing crimes against humanity in the context of 'genocide' ${ }^{17}$, the concept made a breakthrough not only in Argentina but also in the general debate concerning the broadening of its meaning from the original and limited definition. ${ }^{18}$ Daniel Feierstein ${ }^{19}$ dedicated the third volume of his extended analysis of genocide as a social practice focusing on the specific issue of the use of the concept in a trial; as he explained previously:

"One of the most interesting parts in some of the Trials were that the Tribunals decided to hear the testimonies of sociologists, anthropologists, political scientists, philosophers, psychologists, historians, to critically understand what is a national group for different disciplines, and how sometimes the Law uses concepts without any kind of understanding about their meaning. /Last, but not least, we realized during the process how this way of understanding is clearly more accurate and powerful to move back to Lemkin first intuitions and to understand how the only way to really challenge and confront the genocidal thinking and its long after-effects is the legal confrontation with the idea that there are groups who are not part of our group (Armenians, Greeks or Assyrians who are not Turks, Jews who 
are not Germans or Poles, Tutsis who are not Rwandans, Bosnians who are not Yugoslavs, New People who are not Cambodians or Subversives who are not Argentines) and that the killings affects not only the directly persecuted but the whole national group as Turkey, Germany, Poland, Rwanda, Yugoslavia, Cambodia or Argentina could not be the same communities without the annihilated peoples, so the communities have lost something which is part of themselves and not something which is essentially different and alienate from themselves, as the current understanding of genocide seems to suggest.",20

This article uses the concept of "genocide" for the crimes of the 1976-1983 Argentine dictatorship, though also acknowledging that the widespread repression and the systematic use of state terrorism on behalf of the military was carried on within a counterinsurgency war frame formulated in strictly Cold Word terms, as a struggle of socalled Western values against leftist insurgency. We argue that this approach, proper to the International History disciplinary perspective, allows us to better understand the US role during the genocidal counterinsurgency war and repression of the Proceso against the Argentine people. It evolved from the initial loose support of the Ford administration to what we call "the Carter exception" in 1977-79 when Washington denounced the violation of Human Rights and took concrete measures to put pressure on the military to end their campaign. By the end of 1979, however, with the Soviet invasion of Afghanistan the Carter administration ended the Détente and lowered its Human Rights defender profile to get back to the Cold War practice of harsh rhetoric and arms race. The Argentine military, meanwhile, had established contact with the Republican opposition which accused 
Carter for 'abandoning' Washington's Latin American 'friends'. Not surprisingly, therefore, the Argentine dictatorship recuperated US support when Ronald Reagan became the 40th President of the United States. Moreover, they became more involved in Central America where they trained and advised their fellow military in their own counterinsurgency wars, which soon would become part of the Reagan administration's Rollback strategy against an "overstretched” Soviet Union—the "Evil Empire.” The Malvinas War and Argentina's defeat will not only put an end to Washington's support to the Argentine dictatorship but also turn the page of the US support to military dictatorships in Latin America and mark the debut of "democracy promotion."

It is clear that the US involvement in Argentina during the 1976-1983 dictatorship has been lesser and much more indirect than, for example, in the Chilean case. Yet, considering the strategic framing of the Junta's counterinsurgency strategy, the so-called National Security Doctrine, and the role the School of the Americas played in the formation of the military involved in the Proceso, including those who assumed its leadership, the US role cannot be overlooked. ${ }^{21}$ In fact, our main argument sustains that this role is better understood within: a) the structural context of the Cold War in South America; b) the USArgentine relations; and c) the role of the military in Argentine politics. We, therefore, trace-back the formation of the Argentine military in counterinsurgency warfare to the initial French participation and look at the contribution of the School of the Americas. This analytical framing helps us also to better understand the diversification of the Argentine-US relations the military tried when on the one hand they denounced the Carter administration's "anti-Argentine" campaign and, on the other, maintained their ties with the Pentagon and the Republicans. Overall, the Argentine military, as their colleagues in South 
America, enjoyed a good deal of autonomy from Washington when pursuing their own interests and goals. In fact, they were so confident in their autonomy that they believed that Washington would assume at least a neutral position during the Malvinas war...

To elaborate our arguments we have divided the article into five sections. We start with a conceptual assessment of the Cold War in Latin America in general and South America in particular. In section II we propose a brief historical perspective of USArgentine relations since the end of the Second World War. Next, we focus on the special role the military played in Argentine politics since the 1930 coup with an emphasis on their internal divisions in the 1960s between nationalist and pro-US factions. Section IV follows the logic of the military as the main withholders of power in Argentina and discusses the inclusion of the counterinsurgency warfare in their formation under, first, the influence of the French model and, next, the emergence of the National Security Doctrine and the input of the School of the Americas. The fifth section elaborates the main argument of this article about the evolution of the US position with respect of the 1976-1983 military dictatorship from Kissinger's advice to the "Carter exception" and the return of the Cold War "normality" with the Reagan administration. This section also reveals the multilevel relations the Argentine military tried to establish with key players in Washington, as well as their involvement in Central America with the indirect support of the Pentagon. The conclusion highlights the main analytical lines of our arguments and proposes some general reflections.

\section{Section I. The Cold War in the US "Backyard"}


The Cold War is known as a global confrontation of two ideological worldviews under the leadership of the United States and the Soviet Union, the two post-WWII superpowers. However, as Odd Arne Westad argues, it was not always the strategic clash of the two superpowers that shaped the worldwide diffusion of the East/West paradigm of rivalry and conflict: “... Third World elites often framed their own political agendas in conscious response to the models of development presented by the two main contenders of the Cold War, the United States and Soviet Union. In many cases the Third World leaders' choices of ideological allegiances brought them to subscribe to models of development that proved disastrous for their own peoples." 22

Following this argument, during the Cold War Latin America was not a battlefield of the Soviet-American rivalry to expand their zone of influence as much as it was a "killing zone" where the traditional US intervention now wore new clothes branded Containment. According to Rabe, the "Kennan corollary" defined the rationale of the US behavior still aiming at the prevention of the spread of communism, "which Kennan predicted would come not from external attack but through internal subversion. Rewriting the history of the Monroe Doctrine, Kennan believed the United States had the diplomatic tradition to demand the exclusion of Communists from the hemisphere. Not surprisingly, Kennan doubted whether Latin Americans had the societal resolve to resist the blandishments of the Communists. Kennan therefore concluded that "harsh governmental measures of repression may be the only answer; that these measures may have to proceed from regimes whose origins and methods would not stand the test of American concepts of democratic procedure; and that such regimes and such methods may be preferable alternatives, to further communist successes.","23 
Hardly, however, was there any communist upsurge in Latin America when George F. Kennan, the well-known American diplomat who was the Mr. X of the 1947 Foreign Affairs article, "The Sources of the Soviet Conduct," wrote a 10-thousand-word report to the Secretary of State after his 1950 s tour to a region that he confessed barely knew. Rather, with external encouragement during the Second World War, a wave of democratization had spread between 1944 and 1946 in the whole region. "Authoritarian regimes tumbled across the hemisphere, and democratic leaders initiated agrarian and labor reforms, expanded political rights and unveiled social security programs. The degree of ambitiousness varied from country to country, but the general trend was unmistakable." ${ }^{24}$ This wave of democratization improved the social and economic conditions of the lower and middle classes and empowered them; but it also raised the concern of the conservative classes, the traditional landowners and power holders who reacted supporting military coups, authoritarian governments and widespread repression. Even if the US did not determine the ascendancy of the conservative classes and authoritarian regimes, "[t]he emergence of the Cold War certainly heightened ideological polarization, debilitating the popular front and leading to a rash of anticommunist legislation in countries that had only recently been ruled by social democratic coalitions. U.S. support for popular alliances cooled as well, and few of the military governments that came to power found it difficult to establish good relations with Washington."25

It is, then, within this analytical framing of, on the one hand, the US ideologicaldriven spread of the Containment to Latin America, and, on the other, the conservative classes concern of the empowerment of the popular classes for which they welcome Washington's militant anticommunism that the Cold War made a late coming to the region. 
This analytical framing helps understanding the role that the Latin American military played in diffusing the Cold War and used its paradigm in their own war against the popular classes. Thus, while the Cold War was "pushed" to Latin America in the "years following World War II"26, the 1954 coup in Guatemala that overthrew the democratically elected government of Jacobo Arbenz Guzmán with the active involvement of the Central Intelligence Agency (CIA) authorized by Eisenhower's National Security Council (NSC) on August 12, 1953, became, as Rabe characterizes, "the mother of interventions" ${ }^{27}$. The 1962 Cuban missile crises, the only US-Soviet stand-by Cold War episode in Latin America, stretched even more Washington's relationship with the military; already in 1961 Washington had assigned to the 1946-founded US. Army School of the Americas the specific goal of teaching anti-communist counterinsurgency training, which would lead to more CIA backing of coups and "dirty wars" against "subversive" movements as planned in the "National Security Doctrine."

Yet, this does not mean that the prime responsibility for the military takeovers and repressions everywhere in Latin America goes to Washington. It is true that the Cold War paradigm reached the continent as part of the Containment Grand Strategy but, as argued, with the absence of a direct US-Soviet stand-by in Latin America it became a useful ideological framing for the local elites and the military to pursue their own interests and power projects. In other words, Latin American elites and the military performed in rather broad autonomy. In fact, they had their own goals and were eager to pursue them independently of the US strategic interests. This is especially the case of Brazil despite its historically close relationship with the US and an ally during World War II, but also of 
Argentina, which, as the next section shows, had maintained its distance with Washington and declared neutrality till the very end of the fall of Nazi Germany.

\section{Section II. Argentina's (Historical) Problematic Relationship with Washington}

According to Roberto Russell, since its consolidation as a nation-state by the end of the 19th century Argentina's foreign policy went through three major cycles. During the first of these cycles (1880 - 1930), the ruling elite reached a wide consensus with respect to Argentina's position in world politics, which consisted in "affiliation to the European sphere, opposition to the United States ... relative isolation from Latin America and the defense of peace as presupposition of peace." ${ }^{28}$ With the encouragement of Great Britain, Argentina rejected the US proposal to form a continental customs union during the First All American Conference in 1889-1890 in Washington and stopped the latter's ambition to gradually displace London and reach a position of primacy in the continent; and despite that after 1916, Argentina imported more manufactured goods from the US the British market continued to be the main destiny of Argentine products. With the world economy entering the era of Depression, in Argentina the military came into power and the state's intervention in the economy increased. With the election of the charismatic military Juan Domingo Perón in 1946, the second, and so far longest, cycle of Argentina's foreign policy reflected the inward development model known as the Import Substitution Industrialization. Despite the end of World War II, and based on Perón's conviction about the inevitability of the next one, Argentina rejected the US-promoted multilateralism to concentrate on 
strengthening the internal market and protecting it from external shocks while, simultaneously, bringing back the relations with Latin America on the foreign policy's agenda within the framework of a "closed regionalism" development model. Thus, Argentina's membership to international organizations such as the International Monetary Fund, the World Bank and the General Agreement on Tariffs and Trade was deliberately delayed until the second half of the 1960s.

"The search and preservation of the national autonomy determined also the country's approach to the East-West conflict. Perón's Third Position and the "independent" policies of the following governments aimed at distancing Argentina from both camps and building a world order that would give more opportunities to countries that later would become known as the "South." This policy generated close relations with the positions of nonalignment and neutrality that blossomed in the developing world from the mid-1950s. Argentina never kept an equidistant position between Washington and Moscow; however neither did it accept to bandwagon with the U.S. The non-equidistant position meant that Argentina would not be neutral in case of a rising tension between the two superpowers. Rejecting to bandwagon with Washington meant that it would not assume automatically positions that the U.S. interests dictate. Little had remained of the old rivalry and systematic discrepancies based on the need to maintain the economic links with Europe; Argentina needed now to fix the differences of its own interests with respect to the broader power asymmetries, as well as 
distinguish between West's strategic conveniences and global politics and the U.S. national interests." 29

Thus, it is the rationale of the economic development models during both 1880 1930 and 1946 - 1983 foreign policy cycles the main explanatory factor of Argentina's problematic relationship with the US; not a so-called "political culture" inherited from the Catholicism of the Spanish Empire, which is fundamentally anti-liberal and sympathetic to authoritarianism, as some analysts sustain ${ }^{30}$. In fact, the model was essentially liberal when Argentina emerged as a rapidly developing country by the end of the 19th century and was recognized as one of the richest countries in the world when it celebrated the Centennial of the Revolution in 1910. The Argentine oligarchy, the ruling elite of the so-called Conservative Order at that time, privileged its relations with Europe and Great Britain beyond any other consideration. Likewise, when the global center-periphery trade system of the 19th century entered in crisis and collapsed in 1929, the inward development model of the Import Substitution Industrialization proved to be a success to avoid to the country the painful economic depression that most of Europe and the US suffered.

This is important to understand, because even if Fascist and Nazi sympathies in the country in the 1930s and during World War II cannot be underestimated, Argentina's neutrality during the war is linked to the ISI. Moreover, Perón's rise after the war as a popular leader, as well as his political doctrine is based primarily on the success of the ISI in a historical context when the US tried to build the postwar order and consolidate its hegemony in the Western Hemisphere. For, though for the US. Argentina already was "the black sheep of the hemispheric community"31 because of its neutrality during the war, it was the open, and unwise, campaign of the US ambassador, Spruille Braden who arrived to 
Buenos Aires on May 19, 1945, against the then de facto President, Edelmiro Julián Farrell, and the rising political star of that time, Juan Domingo Perón, that backlashed and deeply marked the US-Argentine post-WWII split. For Argentine voters, "Braden o Perón," Perón's 1946 electoral campaign slogan, “identified the General as the candidate who was opposing to the U.S. denomination and promising to promote Argentina in world politics. ${ }^{, 32}$ Since then it has remained as an icon of Argentines' reluctance to foreign, especially US, intervention in internal affairs. The Braden-Perón episode became a benchmark for analysts to identify Argentina's anti-Americanism with the emergence and persistence of the Peronist movement. This at least is an exaggeration and a historical imprecision. This section argues that the development models that Argentina adopted explain its push for autonomy in foreign relations and, therefore, its everlasting suspicion of US hegemonic drive. This is a crucial explanatory variable, For example, after Perón's destitution with a coup in 1955 , the military's growing identification of the national security with a closer alliance with the US led to the ratification of the Organization of American States' Charter, the inclusion of Argentina in the US-created international institutions such as the IMF and the Eisenhower administration's direct financial support to the new government ${ }^{33}$. In spite of this, the country's elite remained eager to hold on proper criteria when deciding on foreign relations even when it irritated Washington. Such is the case of Arturo Frondizi's government's decision not to break Argentina's relations with Cuba in order to counterbalance the opening to the United States until February 1962, and even in spite of that, after a month the military once again disrupted the Constitutional $\operatorname{order}^{34}$. 
From that moment on the United States' main focus will be the insistence on counterinsurgency, which, in turn, provided the military the main frame to elaborate the socalled National Security Doctrine and justify their permanence in power at the cost of democracy and civilian rule. The next section highlights the role of the military in Argentine politics from a historical perspective. This will allow us to rationalize the importance of the US-promoted counterinsurgency in repression, violation of human rights, state terrorism and genocide.

\section{Section III. The Long "Hour of the Sword": The Military in Argentina's Politics}

On December 17, 1924, in Lima, Peru, the Argentine poet Leopoldo Lugones gave a public speech on the occasion of the Centennial of the Battle of Ayacucho. In this speech, Lugones famously said: "Once again, for the good of the world, has announced the hour of the sword." ${ }^{35}$ Rejecting "pacifism, collectivism, democracy," he glorified the army as "the last aristocracy ... the last hope for a hierarchical organization left for us in the midst of a demagogical dissolution." Lugones' discourse, as would later be correctly interpreted, was nothing less than an invitation to the military to intervene in politics. Six years later, on September 6, 1930, General José Félix Uriburu performed a military coup against the Constitutional government of Hipólito Yrigoyen and established a dictatorship. It will be the first of the long "hour of the sword" in Argentina that would last till 1983. For 53 years, and with the exception of Perón's reelection in 1951, every civilian rule was interrupted by a military coup imposing 14 dictators who were declared "President." 
Military intervention in domestic politics was not, of course, new in Argentina. Even during the first Yrigoyen Presidency, they intervened to brutally repress workers strikes in Buenos Aires (1919) and the Patagonia in 1921. "Military intervention was encouraged by the specter of subversion after World War I. In Argentina fears of communism were heightened by the presence of an urban working class consisting primarily of foreigners ... A highly politicized and militant labor movement emerged during and after World War I, supposedly encouraged by the demagogy of the populist party in power. Populism provided an excuse for subversion, according to Conservatives, with the implication that the democracy of the polls was illegitimate. It also provided an excuse for military coups aimed at repressing the conditions of subversion in populist demagogy."36

However, it is important to remember that, first, the Supreme Court, turning to Roman Law, ruled in 1930 that the armed forces may legitimately displace an elected government because they have the task of protecting life, liberty and property. From that moment, the legalization of the 1930 coup, first institutionalized the military rule; and, second, the "idea of a coup was first implanted by civilians, who approached retired general José Félix Uriburu in 1927 in the hope of preventing Yrigoyen from being reelected. ${ }^{\text {37 }}$ In fact, civilian support to coups and dictatorships will become crucial for the self-legitimation of the military when justifying repression.

The institutionalization of the military intervention in domestic politics is one of the topics most widely studied. Robert A. Potash ${ }^{38}$, Alain Rouquie e $^{39}$ and David Pion-Berlin ${ }^{40}$ among others have written intensively about the rise and evolution of the military, their involvement in politics and relations with the civilians. Thus, according to Potash, a series 
of reforms at the end of the 19th century and the beginning of the 20th driven mostly by the fear of a war with Chile modified deeply the military organization. These reforms included: the creation of the Higher School of War in 1900; the draft in 1901, known also as Ricchieri's Law following Pablo Ricchieri who at that time was the Minister of War; its reform in 1905 to include the Navy; and the professionalization of career promotion. "One of the most significant aspects of the importance of the professionalization after 1900 has been the diffusion of the German military influence through advisors, training programs in Germany and armaments." ${ }^{41}$ Argentina had signed several contracts with German companies in the 1890s for the acquisition of arms and equipment. Moreover, in 1899, German officers were invited to organize the War Academia leading in the following year to the adoption of the Prussian models in the organization of the different institutions, such as the Shooting School and the Military Geographic Institute. "The influence of the German military concepts within the Argentine officer corps deepened further with the constant practice of sending selected officers for additional training to Germany."42 Among these officers was José Félix Uriburu, who was a firm supporter of Argentina's neutrality during World War I; thus, though not the main cause, the German influence on the military institution in its earlier stages of formation explains at least partially the Argentine neutrality during both World Wars in the 20th century. It also is related to the rise of nationalism in the 1920 s and 1930 s as a reaction to liberalism at a historical moment when the economic development model based on free trade enters in crisis. As David Rock has written, nationalist ideas in the 1930s penetrated the Army. "They also developed their own critical philosophy to liberalism adopting a militant anti-imperialism that deeply questioned the relations of the oligarchy with Great Britain, the main investor and buyer of Argentine 
products." ${ }^{43}$ Thus, Argentine anti-liberal nationalism, very popular among the military, initially was not anti-American as much as it was anti-British. It nevertheless had its impact on the relations with the US after the rise of this latter as the liberal superpower and inheritor of Great Britain after World War II.

However, after the fall of Perón and with the expansion of the strategy of Containment across South America, the military's position toward the US changed. Not precisely because the military became liberal; rather, the Cold War and US assistance provided them the ideological argument, the political support and the know-how to remain in power.

The foreign policy of the Revolución Libertadora, the name that the military gave to the 1955 coup that interrupted Perón's second mandate, adhered to US positions on the international stage ${ }^{44}$. After the brief interlude of Kennedy's Alliance for Progress and engagement with democracy, the US policy turned to counterinsurgency as the main guideline of its policy in the Latin America. Counterinsurgency was the US reaction to Khrushchev's reach to the Third World and Castro's ambition to expand the Cuban revolution in the region. Counterinsurgency implied the participation not only of the Pentagon, but also the CIA, FBI and USAID's public security program ${ }^{45}$. In Argentina, the public opinion and the political elite continued strongly favoring national sovereignty. So did the military, though as early as 1956 some high ranking officers started to ask for a "democratization" of the armed forces and criticized the dominant Prussian tradition. Meanwhile, the Pentagon started to send pedagogical material to Argentine military schools and invited an entire class of graduated from the Military College to realize a course in the US $^{46}$ From 1960 on, "the communist danger" became a dominant topic in the Argentine 
conservative press, and, seldom, synonymous to anti-Peronism. The military shared this common ground; however, soon an internal division separated the ultraliberals from the nationalists. In 1962, the tension between the two factions reached at its highest level bringing the country at the edge of a civil war. Within this division, the faction that became known as the Reds (colorados) identified Peronism with a sectarian and violent class movement that leads to communism. For the Blues (azules) despite its errors, excesses, power abuses and demagogy, "Peronism is a national and Christian force that saved the working class from communism and, therefore, was a pillar against subversion." ${ }^{, 47}$ They opposed Perón from a professional perspective considering that he politicized the armed forces; else, they were deeply anti-liberal and nationalist. In fact, their leader, General Juan Carlos Onganía, the head of the so-called Argentine Revolution (Revolución Argentina) that ended the presidency of Arturo Ilía in 1966, called for an Argentine-Brazilian cooperation to fight communism in the Western Hemisphere. "At the beginning of the Onganía regime, anticommunism and the national security doctrine had become a doubleedged sword for Argentina's foreign, as well as domestic politics. Superficially it defended the need to hold a close cooperation with the U.S., however it received the broad support of anti-democratic and nationalist military and civilian sectors who were openly hostile to the United States."

It is clear, therefore, that when counterinsurgency became the leading paradigm of the US policy in Latin America, the Argentine military adopted it to perpetuate their power. The next section looks at the role that the counterinsurgency played in the formation of the military from its earlier, French, model to the input of the School of the Americas. 


\section{Section IV: The Evolution of the Counterinsurgency to a National Security Doctrine: From the French Model to the School of the Americas}

Though counterinsurgency as a warfare strategy goes back to the 19th century, its modern version in the 20th century is a "made in France" product, as it is the French colonial experience in Indochina and Algeria ${ }^{49}$ that settled the conceptual and practical bases of the strategy that the US applied in Latin America, Vietnam, Central America, Afghanistan and Iraq from the 1960s to current days. The Argentine military were among the first to study the French experience with the immediate assistance of officers directly involved in operations in Indochina and Algeria. Thoroughly documented in Marie Monique Robin's mentioned study and documentary, the counterinsurgency strategy, including torture and disappearance of captured insurgents, that the French invented and experimented in Algiers ${ }^{50}$ started to be taught in the Training Center headed by the then Minister of Defense, Jacques Chaban-Delmas. French, Portuguese and Israeli officers were formed there following the instructions of the manual Modern Warfare authored by Roger Trinquier. In 1964, Colonel David Galula published Counterinsurgency Warfare: Theory and Practice, whereas Jean Lartéguy's novel The Centurions (1963), adapted into the motion picture, Lost Command, in 1966, popularized the topic.

As early as 1959, the French and Argentine armies signed a deal to create a permanent French military mission in Buenos Aires under the direct auspice of the Argentine Chief Staff. All the members of the French military mission were veterans of 
Algeria and operated in absolute secrecy. According to the testimony of one of them, Bernard Cazaumayou, their mission consisted in teaching the anti-revolutionary warfare. Thus, with funds provided by the Argentine Army, they translated Triquier's manual and taught. The French mission ended in 1961 when Buenos Aires organized the "First InterAmerican Course of Counterinsurgency Warfare" with the participation of delegation from 14 countries including the United States. In fact, according to the testimony of French and American officers, the Americans showed great interest for the French model that they implemented in Vietnam in 1967 with Operation Phoenix in Saigon replicating the model of the battle for Algiers with tragic consequences: 20 thousand civilians killed by Death Squads chasing Viet Cong guerrillas.

Thus, while it is true that, as will be explained next, the School of the Americas played an important role in the development of the National Security Doctrine in Argentina as in other Latin American countries where the military has launched a counterinsurgency warfare by providing the ideological argument and the support of the superpower, the French model had a deep and enduring impact. All the members of the 1976 military junta, for instance, had been students of the French school. Moreover, Colonel Robert Servent, a former officer who served in Algeria and hated De Gaulle for his "betrayal," headed a French mission that arrived in Buenos Aires on April 15, 1974 to "study" the successive phases of the Argentine dirty war from his office on the 12th floor of the Army's central building till October 2, 1976. He was one of the closest friends of Argentina's last dictator, General Reynaldo Benito Antonio Bignone, who, on May 18, 2003, accepted to give an interview to Robin. In this interview, Bignone considers that the French influence was "no doubt" deeper than the American and it lasted throughout the 1970s. "I would say that the 
National Reorganization Process that the military government implemented in March 1976 is a copy of the battle for Algiers. The only difference is that you intervened in a colony whereas we did it in our own country. This exception aside, we learned everything from the French: the division of the territory, the importance of intelligence in this sort of warfare, the methods of interrogation..."51 Like the other members of the Junta, Bignone shows no remorse at all for using torture. "We won the military battle, but we lost the political one, just like the French in Algeria! Our biggest mistake was to accept the term of "dirty war," because no war is clean: innocent people die in every war. And it is my conviction that the National Reorganization Process provoked less death then any classical war..."52

The French model's foundational influence notwithstanding, counterinsurgency as a strategy of Containment in Latin America is essentially the way the US fought the Cold War in the region relying on the local military as allies to whom Washington provided the ideological, theoretical and practical support and helped them first in their efforts to elaborate the National Security Doctrine and then implement it. Counterinsurgency was also the conceptual framing of the violent repression of the Latin American military against their own people with the support of local oligarchies, a process through which the military became the main agents of the "Latin Americanization" 53 of the global conflict and the diffusion of the Cold War paradigm in the region. This was done though the elaboration of a series of programmatic principles labeled National Security Doctrine that justified counterinsurgency as a strategy of Containment against communism. "The National Security Doctrine marked a fundamental change in the role of Latin American armed forces. Their mission was no more to secure the borders but to look for and try to identify the enemy within the proper country. Despite that armed organizations (generically labelled 
as "guerilla" or "armed subversion" by the military) defined primarily the internal enemy, the repression targeted a broad arc political opponents: communist, socialist, antiimperialist militants, peasant and labor unions, student movements, church communities linked to the Liberation Theology, as well as any group of nationalist color that would presumably threaten the "national security.","54 Though several US military institutions participated to the formation of training of Latin American officers for the counterinsurgency war, the School of the Americas in Panama played a crucial role in it. Founded in 1946 during the Truman administration, the School of the Americas' headquarter, known as Fort Gulick, became the center where for the next 50 years 59000 Latin American military personnel, policemen and civilians were trained. "Ten of the graduates of the school became the president/dictator of their countries, 23 became ministers of defense, and 15 ministers of other departments." ${ }^{55}$ With respect to Argentina, Washington's involvement in the training and support of the military, as well as in terms of economic aid during the period of the expansion of the counterinsurgency in Latin America was substantial: 810 million in military aid alone between 1960 and 1975, and 4017 Argentine military personnel trained during several administrations. These numbers alone led Gareau to conclude that " $[t] h e$ evidence indicates that the training given was intended for such an eventuality as the dirty war and that Washington is guilty of being an accessory before the fact."

In what follows, we try to put in context this argument about the US "guilt" focusing on Washington's policy during the Proceso.

\section{Section V: The US and the Genocide in Argentina}


Perhaps the most remarkable success of American-led training for counterinsurgency and the role the School of Americas play in creating a common mindset among Latin American military is Operation Cóndor, a broad plan of cooperation among the dictatorships to share intelligence in locating political opponents and eliminate them. Cóndor meant "the 'continentalization' of political criminality," according to the Chilean writer and politician Volodia Teitelboim ${ }^{57}$. Arguably, the secret plan was first revealed in the aftermath of the assassination in Washington DC of the former Chilean Minister of Defense and Ambassador in US, Orlando Letelier, in September 1976 by a task group of Pinichet's agents, the former C.I.A. member Michael Townley and anti-Castro Cuban terrorists. F.B.I.'s Special Agent Colonel Robert Scherrer posted in Buenos Aires, sent a cable to his superior son September 28, 1976, informing that Operation Cóndor is "the codename to the collection, exchange and stocking of intelligence information about the socalled leftists, communists or Marxists that created not long ago the secret services in South America to cooperate for the elimination in the zone terrorist-Marxist activities."58 The name was conceived in Chile, sustains Sergio Buffano, a former Argentine communist militant, member of Fuerzas Armadas de Liberación (Liberation Armed Forces) and founder of the trimestral publication Lucha Armada (Armed Struggle) in 2004 to critically review the violence of the 1970s; however, the proto-Cóndor planning started in February of 1974 with the first meetings between the Argentine, Uruguayan, Chilean and Bolivian heads of state where the decision was made to take actions against all leftist groups. ${ }^{59}$ For Jair Krischke, the president of the Brazilian organization Movement for Justice and Human Rights, though Operation Cóndor was founded on November 1975 in Chile, the kidnapping and torture of the Brazilian democratic military, Colonel Jefferson Cardim Osorio, on 
September 11, 1970, an operation for which the secret services of Brazil, Argentina and Paraguay cooperated in the exchange of information as revealed in the report 001061 of the Brazilian National Information Service proves that the plan was already working at that time $e^{60}$.

Operation Cóndor became widely known after the 1992 discovery of the Archives of Terror, ${ }^{61}$ which provided new and documented evidences of its functioning. Based upon the revelations of these documents, Calloni accuses the US for providing "inspiration, funding and technical assistance to the repression and might have planted the seeds of Operation Cóndor. The C.I.A. assured better coordination between the secret services in the region ... [it] also performed as intermediator of the meetings between Brazilian, Argentine and Uruguayan leaders of deaths squads." ${ }^{62}$ Patrice McSherry states "[w]e now know that the State Department, the Defense Department, and the CIA were well-informed of Operation Cóndor, of what the CIA calls "the precursors to Cóndor" years before 1976 and that US agencies supported or collaborated with some Cóndor operations." ${ }^{\text {63 }}$ Yet, this happened when the United States was preparing the Détente with the Soviet Union, and, according to Mark Atwood Lawrence, "Latin America ranked at the bottom of Richard Nixon and Henry Kissinger's global priorities." ${ }^{64}$ The zero importance of Latin America for international politics and History in general that reportedly both the 37th President of the United States and his National Security advisor never bothered at least not expressing publicly, led to a policy aiming at a low-key preservation of the status quo relying on friendly dictators. This meant basically abstaining from any interference in the way Latin Americans, mainly military rulers, assured the maintenance of the status quo. However, if on the one hand this lack of will to interfere in domestic affairs indeed gave greater 
autonomy to the Latin American military, and, therefore, alienated the region from the US when Jimmy Carter made of the respect for human rights a pillar of his foreign policy; on the other, it created confusion with respect to the US role in the widespread repression of the military governments to their own people. First, the supposedly low-key importance of Latin America for the Nixon administration, and therefore the lack of intervention, also meant the continuity of the counterinsurgency approach and its implications for the training and support to the military. Second, the US agencies involved in the specific programs of training and support, hence a direct contact between the provider and the customer continued. Third, more importantly, the Nixon administration's "low profile" in Latin America is a highly questionable judgement. This is due to several factors: first, Nixon's interest in forging a special relationship with the Brazilian dictatorship ${ }^{65}$ and Kissinger's attempt to make of Brazil a US "policeman" in the region much in the way Iran has become in the Middle East; ${ }^{66}$ second, and most important, its role in first undermining the democratically elected government of Salvador Allende in Chile, and then the active support given to General Augusto Pinochet's coup on September 11, 1973. ${ }^{67}$ Therefore, it is not surprising that while the two superpowers enjoyed Détente in their relationship allowing a European opening to their Eastern neighbors and a German Ostpolitik, Latin America went through the most violent period of the Cold War. The US predominant counterinsurgency approach to Latin America during the 1960s and the beginning of the 1970s succeeded in installing the Cold War in the region leading to high-ranking officers to think and declare that "the Southern Cone had become the central front of a "Third World War" between communism and the West." 68 
The Proceso and the genocidal repression in Argentina are part of this "Third World War" that the military "fought" against their own people convinced that they were assuming their share of responsibility in the global contingency of the Cold War. Arguably they expected if not Washington's support at least its comprehension as was the case for other military coups in neighboring countries; and, probably, they did not expect a serious demand for Human Rights respect as will be the case with the Carter administration. Yet, while Operation Cóndor was going on in South America, Carter's Secretary for Human Rights, Patricia Derian, and Tex Harris, the US diplomat who was in charge of the Nuclear Affairs in the Embassy but assumed an active role in the defense of Human Rights, pressured the Junta to allow a fact-finding visit of OAS' Inter-American Commission for Human Rights. Not everyone in the Carter administration of course approved this exception in US policy toward their Latin American "friends"; the Argentine military found sympathizers and allies such as the then Secretary for Latin American Affairs, Terence Todman, who later in the 1990s became the US. Ambassador in Buenos Aires, as well as the Republican politicians in Washington who never shared Carter's enthusiasm for Human Rights; not, at least, at a price as high as the alienation of the Latin American military. Therefore, when at the end of 1979 with Carter still in the White House the Cold War made a comeback after the Soviet invasion of Afghanistan and the American reaction to end arms control negotiations and return to massive military building, the Argentine military thought they had resisted well and won. By then, they were already engaged in the Central American conflict advising their colleagues in Honduras and El Salvador; their hope, therefore, for an unconditional US backing with the election of Ronald Reagan was so high 
that they did not hesitate to declare war to the United Kingdom for the recuperation of the Malvinas islands...

In what follows, we analyze the US policy toward the Proceso in three periods: the end of the Ford administration; the two years of the Carter exception; the return of the Cold War and Reagan's first year till the Malvinas war in 1982. We mostly focus on primary sources, declassified US documents ${ }^{69}$ during the years of the repression, but use also secondary ones in an effort to explain Washington's policy and its evolution, as well as dissents from the official position within the US successive administrations from 1976 to 1982. We aim at making a case of our main argument about the role the US played in the genocidal repression providing the ideological frame and the know-how of the counterinsurgency coercion that it built in the previous two decades, ${ }^{70}$ and, therefore, had not been able to deter the Argentine military from reaching the unprecedented levels of atrocity in their criminal enterprise.

Section V.a. Ambassador Hill's Initial Support and Quick Deception: The Last Days of the Ford Administration (1976). The US. Embassy in Buenos Aires knew about the March 24, 1976 military takeover before it happened. On February 13, Diego Medus, head of the North American desk at Argentina's Foreign Ministry, informed the Embassy that the military requested a report about how to avoid human rights problems with the United States during a future military government. He also set clear that the military had the intention to engage in illegal violence while carrying forward an all-out war against "terrorists." ${ }^{71}$ Yet, Robert Hill, the U.S, Ambassador in Argentina, who already considered that the military were the only hope for restoring stability, found encouraging the awareness of the Argentine officers to avoid irritations with Washington for human rights problems 
and supported their political aspiration. In a telegram to the Assistant Secretary of State on March 16, 1976, Hill informed about his conversation with Admiral Massera the same day and commented: "Admiral Massera was very correct throughout the conversation. $\mathrm{He}$ scrupulously placed all his comments in the conditional tense, and several time emphasized that he was speaking hypothetical possibilities. Nonetheless, Pol Couns and I had the distinct impression that Massera was talking about a coup which will probably come within the next few days, possibly before the weekend." 72 The imminence of a coup, along with the conviction that the Argentines will support it, is asserted in an Embassy telegram two days before the takeover. ${ }^{73}$ Hill was all too confident that the Argentine military had changed and were more democratically minded than a decade ago; moreover, he was convinced about Videla's "moderate line,"74 and almost a month after the coup he sustained that the Junta had nothing to do with the violation of human rights: "Our political sources, plus U.S. newsmen here (who are very sensitive to human rights issue) continue to express surprise that Junta had acted with as much moderation as it has so far, given the atmosphere of left-right terrorism which the country has endured for the last three years. Its policy is to respect human rights." "I5 "In fact, the Argentine military had changed in the ten years since the Onganía coup, though not in a moderate direction." ${ }^{, 76}$ At its final stage in 1975, the Argentine military's national security doctrine asserted that the country was at the front stage of a world war against communism. "War" was not a metaphor; it meant counterinsurgency and, therefore, was synonymous to the repression the military carried on. This is why "less than two months after the Argentine military coup on March 24, 1976, Hill was beginning to have serious doubts regarding the validity of the military junta's selfproclaimed "moderate line." Although the ambassador, along with most Argentines, 
continued to view Videla as a moderate, Hill was disturbed by reports of the three armed service branches operating independently of each other and engaging in widespread arbitrary arrests." ${ }^{, 77}$ A telegram from the US embassy on May 11, 1976 started to cast doubt on the military "moderation," concluding: "Whatever his motives, fact is that Videla has not come to grips with situations and stopped drift toward harder line. In embassy's judgement, unless he or someone else does, Junta will soon face serious difficulties both at home and abroad—abroad, because hardliners will give little attention to human rights and will create same sort of situation faced by Chilean Junta; at home, because hardliners will alienate major sectors and create conditions under which leftist/extremists will pick." ${ }^{78}$ By the end of May, Hill had already become strongly critical to the Junta and personally warned Foreign Minister Cesar Guzzeti that US-Argentine relations will suffer seriously if the government does not improve its human rights record. Yet, his attempts to pressure the Argentine military were neutralized by the Secretary of States' approach to US-Argentine relations; Kissinger cancelled seven visits that Hill prepared convinced that high-level US pressure could play a role in curbing the Argentine dirty war. Finally, Kissinger met Guzzeti in Santiago de Chile to, as mentioned earlier in this text, assure "we would like you to succeed," advising, however, "if there are things to be done, you should do them quickly." ${ }^{, 79}$ This was enough for the Junta to conclude that there was no real problem with the US and their criminal enterprise could go on without any serious foreign threat. Later, "Hill detailed his lonely efforts to protect human rights in Argentina to the assistant secretary of state for human rights and humanitarian affairs Patricia Derian on her first trip to Buenos Aires following Jimmy Carter's electoral victory over Gerald Ford. "Kissinger gave the Argentines the green light," the ambassador bluntly concluded." ${ }^{80}$ 
Section V.b. The Carter Exception (1977-1979). No Latin American dictatorship expected a US administration to take the issue of human rights seriously enough to put pressure on loyal allies in the battle against communism. Certainly not the Argentine junta after Kissinger's support, though he also warned about a change following a Democrat electoral success. Yet, the Carter administration's first two years at least had been an exception in US policy toward Latin America. The 39th President of the United States used a series of amendments to the 1961 Foreign Aid bill that Congress had legislated from 1973 to 1976 following the Vietnam war to implement sanctions to human rights violations, including limiting and, eventually, stopping economic and military assistance. If the congressional action aimed at first hand to impose further control on the Executive Branch, it, nevertheless, also gave activists an opportunity to push the human rights agenda further. Carter recognized that human rights had become a major political issue and embraced it in a way to appeal both to liberal internationalists and cold warriors; while the former aimed at seriously improving the worldwide condition of human rights, the latter saw it as a means of pressuring the communist world. Amidst Détente and arms control negotiations going on with the Soviet Union, the Carter administration policy of human rights encouraged dissidents in communist countries and provided serious support to activists in Latin America. This was particularly true for Argentina, where Patricia Derian arrived three days after the first anniversary of the coup and left no doubt about the uncompromising character of the new administration's demand for respect to human rights. Derian's intransigence surprised officials both in the Argentine government and the US embassy where not everyone shared Ambassador Hill's change of heart with respect to the military. Derian met also with representatives of human rights advocates and relatives of victims of 
state terrorism, a moment of "glimpse into the terror of the Argentine dirty war." ${ }^{\text {" }}$ For the next two years, Argentina became a main target of US pressures aiming at the improvement of human rights while "avoiding the fall of Videla's regime." ${ }^{82}$ Indeed, Carter's policy did not aim at any "regime change," nor did it insist on democracy promotion, which will become central in Reagan's policy toward Latin America after the Malvinas war. Patricia Derian and Tex Harris, the US diplomat who upon his arrival to the US embassy in the fall of 1977 decided to open the doors and for two hours every day receive those who came to denounce disappearances and prepared 9500 individual files to send them to the Assistant Secretary for Human Rights in Washington despite all the threats, including a kidnapping attempt, he and his family received, saved lives, gave voice to the victims of the repression and succeeded in blocking a loan from Eximbank to the Argentine Navy unless the government accepted the visit of a delegation of the Inter-American Commission for Human Rights. In an extended interview Harris gave 36 years after the military takeover during his visit to Argentina, Harris revealed further details about his mission, but also the obstacles to his work he faced in the embassy and the State Department. Praising the peaceful resistance that the Mothers of Plaza de Mayo started against the dictatorship, Harris considers that it was the event that broke Kissinger's anticommunist strategy. "Argentina has been the case that showed to the world what should not be done in the struggle against terrorism. ${ }^{, 83}$ Nevertheless, as soon as his reports started to have a practical impact on US-Argentine relations when, for the first time, Washington denied sending the hamlets the Argentine Navy was asking, Harris faced the new Ambassador's serious discontent: “Ambassador Raúl Castro felt that my reports were impeding his control on U.S. policy towards Argentina. He was a close friend to Roberto Viola and tried to help 
him in the internal drift of the Junta but Washington had no interest for this little war." 84 Moreover, while he continued sending his reports to Derian, US firms continued negotiating secretly with the dictatorship; yet, because of Harris' efforts a major deal involving Eximbank between the US and the Argentine Navy failed because the bank had to cancel the loan. "This was a very important project for the U.S. business community; Trade Department and the Treasury were furious because they considered that Carter's human rights policy was equivalent to a drop in exports and U.S. jobs. Meanwhile, in Argentina the Navy got mad because his future 'fat cow' was suspended because the US government decided not to extend its insurance for the Eximbank loan. ${ }^{\circledR 5}$

Section V.c. The Return to the Cold War Paradigm (1980: Carter's Last Year). Not everyone shared Carter's shift prioritizing human rights over the Cold War paradigm for US policy in Argentina. Not the Pentagon, not the Republican opposition, not even people within his own administration-the so-called "hawks" o career diplomats. Starting with the proper staff of the US. Embassy in Buenos Aires, where Harris soon became a pariah, someone unable to team-play. The main displeased with Harris' engagement and persistence was Ambassador Raúl Castro who not only was disgusted with Harris' direct reporting to Patricia Derian but also advocated a different approach to the dictatorship: he insisted in differentiating between the hardliners and the moderates. ${ }^{86}$ His "prudence" was shared within the State Department where in 1977 Carter named Terence Todman head of the Latin American area. Todman tried to limit the "harm" that the reports of human rights violations were causing to Latin American military governments, including the Argentine Junta. "Todman wanted maximum a discrete pressure from Washington. According to him, it was necessary to avoid the alienation of states and military aligned with the U.S. in the 
region. ${ }^{, 87}$ Ultimatly Harris was marginalized in the Foreign Service, punished for six years and on a list of diplomats on the verge of dismissal because of his "lack of discipline" when, finally, in 1984 he received the Rivkin Prime for his role in Argentina and an interview with Bill Moyers received a strong public recognition and support saving his career. On the other side of the spectrum Todman continued his career and became the US. Ambassador in Argentina in 1989 to become one the leading figures in the drastic shift of Argentina's foreign policy during the Menem government toward a close alignment with Washington. Yet, the main blow to Harris, Derian and the human rights community in the US came with Carter's decision in 1978 to promote both human rights and economic liberalization limiting the use of economic sanctions as a diplomatic tool to pressure the military. Critics to his policy of human rights promotion existed already in Congress where Argentina was a defining test. "While congressional liberals complained that the administration was doing too little—culminating in Senator Kennedy's successful amendment eliminating all U.S. military transfers to Argentina on September 30, 1978- a growing chorus of conservatives criticized Carter for doing too much ... It was the U.S. business community, however, that emerged in the spring of 1978 as the foremost critics of the Carter administration's effort to promote human rights in Argentina." ${ }^{\circledR 8}$ Well-aware of these tensions within the US, the Argentine military challenged the Carter administration actively participating in the Bolivian military coup in July of 1978 and denying support to the US grain embargo to the Soviet Union. Three other events in 1979-1980 led Carter to virtually restrain his human rights policy. "Preoccupied with the ongoing hostage crisis in Iran, the newly installed revolutionary government in Nicaragua, and the one hundred thousand Soviet troops stationed in Afghanistan, in the fall of 1980 the Carter 
administration resigned itself to maintaining a holding pattern in regard to U.S.-Argentine relations, an approach the continued following Carter's decisive defeat to Ronald Reagan in the November 1980 presidential election." 89

Section V.d. The Last Drive of the Counterinsurgency: The Short Junta-US. Relations during the Reagan Years (1981-1983). With Ronald Reagan, US policy toward Latin America returned to its normal course. Military governments were once again less dangerous than communist authoritarian regimes, allies and not pariahs according to Jeane Kirkpatrick. ${ }^{90}$ The new administration restored the status of allies to the Argentine military and incorporated them to his anti-communist crusade in Central America. The Argentine military in turn perceived the renewed US support as a reward to their engagement in Honduras, El Salvador and Guatemala where they were already training their pairs in counter-subversive technics. In other words, the Argentine military were already "exporting" their know-how from Bolivia to Central America and "waiting" the "normalization" of US policy after the Carter brief "exception." 91 The encouragement and support the Argentine military received from the Reagan administration created the illusion that the White House would at least remain neutral during the Malvinas war, if not support Argentina's claim. Reagan not only sided with the United Kingdom, but also the Malvinas adventure of the Argentine military ended the confidence Washington held to Latin American dictatorships. Immediately after the end of the Malvinas war, Reagan inaugurated the policy of "democracy promotion" in Latin America sending a strong signal of the end of US support to dictatorships. In Argentina, the failure in Malvinas, the disastrous experience of Martínez de Hoz economic liberalization and the persistence of the civil mobilization against the military led to a unique transition to democracy in the whole 
region. Not only the Argentine military were refused any participation to the transition process, but also right after the CONADEP report the Alfonsín government obliged the Junta to face a court, which in a 1985 historic decision condemned them for the widespread human rights violations.

\section{Conclusion: The Lessons of Nunca Más}

The Proceso is arguably the worst period in Argentina's history. In no other context the institutionalized violence reached to a genocidal dimension. As this article claimed, there is no evidence of a US direct involvement in the preparation and execution of the March 24, 1976 military takeover and the subsequent dirty war. Argentina was not Iran, Guatemala or even Chile to name few of the countries where the US became directly involved in the overthrow of a constitutional government. Yet, it is a fact that the Argentine military perceived a support from the Ford administration and though faced a couple of "difficult" years with Carter's human rights policy they managed to ignore the pressure and continued their counter-subversive campaign. The impact of these short two years, thanks to the personal engagement of Patricia Derian and Ted Harris among others, cannot be underestimated; it opened practically the only door human rights organizations had to let the world know about the massive violation of human rights and give names to whom Vidella cynically characterized as desaparecidos.

Nevertheless, there was no overwhelming consensus in the US to carry on the human rights campaign to its ultimate consequences. The US. Embassy's staff in Buenos Aires was unpleased with Harris" "lack of discipline"; his chief, Ambassador Castro, 
preferred a nuanced approach distinguishing the "moderate" Vidella from the hardliners. In the State Department, Terence Todman, head of the Latin America desk, disapproved the pressure. In Congress, Carter faced a strong opposition from the conservatives who warned against the alienation his policies would cause to "friends," whereas liberals complained that he did not do enough. More importantly, the business community was absolutely critical for the loss of opportunities in doing business with Argentina as Congress considered legal leverages against aid, loans and investments as tools for pressure. Carter's main mistake was to believe that there was no contradiction between promoting economic liberalization and human rights convinced that ultimately the latter would create norms to the free market. This clearly was not the case, and faced with increasing challenges from Iran to Nicaragua and Afghanistan he finally stepped back in insisting too much on human rights. With Reagan, the Argentine military became so self-confident about their "righteousness" in fighting the "Third World War" and expecting a "reward" for their involvement in Central America before the support Washington would give to the Nicaraguan Contras to fight the Sandinistas and the military governments in Honduras, Guatemala and El Salvador to fight the revolutionaries that they declared war against Washington's closest ally in Malvinas, an adventure the aim which was simply its perpetuation in power. The US support to the Proceso overall, therefore, was indirect.

This, nevertheless, cannot lead to ignore that the Argentine military acted in the context of the Cold War, implemented the counterinsurgency strategy as the Latin American version of Containment promoted in the infamous School of the Americas where they completed their formation and sophisticated the lessons they learned previously from the French School. This gives to the global context in which the Proceso claimed 
legitimacy and acted according to the missionary premises it established its importance when thinking about responsibility in genocide, no matter if, in fact, the context was merely the justifying argument for a dirty war fought primarily for domestic concerns. Indeed, from an International History perspective the context is one of the main explanatory factors for events and phenomena with domestic-international, or local-global linkages. This is the case of Cold War as the leading paradigm of the US foreign policy in the aftermath of the Second World War and the struggle for power with the Soviet Union. As sustained in the beginning of this article, Latin America did not matter as much as Europe or Asia from a strategic perspective for the Soviet Union, which became involved in a stand-by situation with the US only during the Cuban Missile Crisis in 1962; Moscow usually had a pragmatic approach toward a region that geopolitically is complicated and prioritized trade and economic interests. Washington, however, had a historical relationship with Latin America going back as early as the Monroe Doctrine in 1823 and a conflictive dynamics since 1898 in terms of hegemonic pushes and popular resistance.

Argentina has been among the countries that historically rejected the US drive for hegemony and advocated for the principle of non-intervention; furthermore, its trade and development interests imposed the logic of distance and neutrality for US global initiatives, including international conflict in the 20th century. The strategy of Containment and its Latin American version of Counterinsurgency provided for the first time in history an ideological argument that helped if not closing the gap at least building bridges between Washington and the power elite in Argentina—namely the military. As in most other Latin American countries, the Argentine military imported the Cold War and reframed it as a “Third World War" fought against mainly a domestic enemy-its own people. As we made 
our point, with the Carter exception, Washington in general was supportive to the military forcing a fictional distinction between the "moderates" and the "hardliners." In other words, there was very little concern in Washington with the abuse of an ideological argument that legitimized a global struggle supposedly for freedom from authoritarian repression.

Where does this lead us? Are there any "lessons learned" from the US policy toward Latin America when military dictatorships violated human rights and, in the Argentine case, reached a genocidal dimension in the massive repression framed as a "Third World War?" Any rationalization of lessons learned from the past should consider the historical context, in this case the Cold War. Regardless of the practical aspects, Containment as the US. Grand Strategy relied on a strong ideological foundation, which provided a missionary dimension as opposed to the narrow "national interest" rationale to foreign policy. Even if from the US perspective this dimension was deemed necessary or inevitable considering the historical process of the US emergence as a world power, adopting and reframing this ideology, and, with the same token, Washington's tolerance if not encouragement to let it happen, has been one of the major pillars of the so-called National Security Doctrine in Latin America and its Argentine version—the Proceso. In Argentina, Nunca Más meant a widespread awareness to deny any role of the military in domestic affairs; it should include also awareness against the importation of any ideological frame of missionary character as the legitimizing foundation of international/domestic, "internestic," engagement. 
Khatchik DerGhougassian is $\mathrm{PhD}$ in International Studies from University of Miami (Coral Gables, FL, USA). He is a professor at Universidad Nacional de Lanús (UNLa) currently on leave. In the field of genocide studies, his research focuses on the phenomenon of genocide and its prevention discussed within the logic of world politics and the dynamics of power.

Leiza Brumat is a Research Fellow in the Migration Policy Centre at the European University Institute. PhD in Social Sciences (Flacso), Masters in International Relations and Negotiations (Universidad de San Andrés - Flacso - Universitat de Barcelona). She was a lecturer in International Relations, and a Research Fellow for the National Council of Scientific and Technical Research of Argentina until 2017.

\section{Notes}

\section{${ }^{1}$ Marcos Novaro Historia de la Argentina Contemporánea. De Perón a Kirchner} (Buenos Aires, Argentina: Edhasa, 2006), 149 .Original in Spanish, non-official translation by authors. The same procedure will be implemented to all non-English textual quotes.

${ }^{2}$ Stands for Proceso de Reorganización Nacional, or Process for National Reorganization, the official denomination of the military's project to discipline the society through the arbitrary use of violence (Marcos Novarro. 2006. Historia de la Argentina Contemporánea. De Perón a Kirchner. (Buenos Aires, Argentina: Edhasa, 2006)) . This article seldom uses Proceso referring to the 1976-1983 military dictatorship.

${ }^{3}$ Disappearance is, according to Prudencio García, an anti-subversive fighting methodology that a Spanish military commander, José Luis Pitarch, described as "the neatest, most efficient" one, and the Argentine Generals, on September 1975, adopted with 50 votes against 3 as a method to be implemented systematically starting on March of the following year. "The method, based on the clandestine kidnapping, illegal detention, massive torture and, for many thousands human beings, a head-shot, followed by the equally clandestine elimination of the body, all without any judicial intervention, was conceived, with no moral consideration, as the quickest and with unquestionable advantages over the legal way." (García 1995, 411) "They are neither alive, nor dead, they are disappeared," is the controversial answer that Videla gave to a journalist during a press conference in 1979 making a case of a "Christian perspective" on Human Rights... (available on YouTube at: https://www.youtube.com/watch?v=3AlUCjKOjuc\#t=39 Last access on 05.25.2015)

${ }^{4}$ Upon Rabbi Marshal Meyer's proposal the CONADEP report was named "Never Again" ("Nunca Más") following the concept that the survivors of the Warsaw Ghetto adopted to denounce the Nazi atrocities. With this title it was published as a book of 480 
pages by Eudeba, and the first edition of 40000 copies was sold-out within the next 48 hours (Fabián Bosoer, "Juicios, castigos y verdades," Clarín, Suplemento Ñ, 6 September 2014, p. 7). Since then, in Argentina Nunca Más had five editions in 1985, 1998 (twice), 1999 and 2003, and was published in Spain (1985) as well as translated into Portuguese (1985), Italian (1986), English (1986) and German (1987). (Emilio Crenzel, 2008. La historia política del Nunca Más. La memoria de las desapariciones en la Argentina (Buenos Aires, Argentina: siglo veintiuno editores, 2008), Annex 1 and 2)

${ }^{5}$ Donald C. Hodges, Argentina's "Dirty War" An Intellectual Biography (Austin, TX: University of Texas Press, 1991).

${ }^{6}$ It is the late Eduardo Luis Duhalde (1939-2012), a well-known Argentine lawyer and defender of Human Rights who became Secretary of Human Rights during the presidential mandates of Néstor Kirchner and Crisitina Fernández de Kirchner from 2003 uto 2012, who characterized the military government as a "Terrorist State" in a book he wrote in 1983, while he was exiled in Spain, and published in Argentina the next year (Eduardo Luis Duhalde, El estado terrorista argentine, (Buenos Aires, Argentina: Colihue, 2013). By that term, as Fernando Bogado correctly states, Duhalde highlighted the central characteristic of the dictatorship: "The control of the repressive apparatus of the State over the forms of the ideological apparatus. As such, it succeeds submitting the civil society to a real and symbolic violence, which, throughout the years, would assure maintaining the necessary conditions to implement the economic receipts that the power dictates." (Fernando Bogado, “El poder y la fuerza," Página/12 Suplemento Radar, 3 March 2014, p. 30)

${ }^{7}$ Ruth Blakeley, State Terrorism and Neoliberalism. The North in the South. New York: Routledge, 2009), 5..

${ }^{8}$ For the economic beneficiary of the Argentine military dictatorship see Horacio Verbitsky and Juan Pablo Bohoslavsky, eds., Cuentas pendientes. Los cómplices económicos de la dictadura. (Buenos Aires, Argentina: siglo veintiuno editores, 2013)..

${ }^{9}$ As DerGhougassian argues, the Cold War in Latin America was less a SovietAmerican battlefield to expend their area of influence with the exception of the Cuban Missiles episode in 1962 and more the "diffusion" of the global conflict by local dominant elites as an argument to contain and repress the emergence of the masses and their demand of inclusion in the political and economic processes. Section I of the article follows this argument in its general guidelines. (Khatchik DerGhougassian, "Last-in, First-Out? The Diffusion of the "Short" Cold War in Latin America," unpublished paper presented at the 
International Studies Association Annual Convention in San Francisco, panel "The Tide of Ideas in Latin America," 6 April 2013)

${ }^{10}$ Ruth Blakeley, Op. Cit., p. 19.

${ }^{11}$ Khatchik DerGhougassian, "Bajo la sombra de la Guerra Fría," La Nación Suplemento Enfoques, 19 March 2006. On the Web at:

http://www.lanacion.com.ar/789805-bajo-la-sombra-de-la-guerra-fria Last access: 03.21.2006.

${ }^{12}$ The CONADEP report is available on the Web at http://www.dhnet.org.br/direitos/mercosul/a_pdf/nunca_mas_argentino.pdf that is used for quotes in this article (accessed on 05.16.2015).

${ }^{13}$ Gareau Frederick H. Gareau, State Terrorism and the United States From Counterinsurgency to the War on Terrorism (Atlanta, GA: Zed Books, 2004), loc. 1856 of 4620 [Kindle DX version]. Retrieved from Amazon.com

${ }^{14}$ Marie-Monique Robin, Escuadrones de la muerte. La escuela francesa, translation: Sergio Di Nucci (La Plata, Buenos Aires Argentina: De la Campana, 2014).

${ }^{15}$ See, for instance, Hugo Vezzetti, Pasado y presente guerra, dictadura y sociedad en la Argentina. Buenos Aires, Argentina: siglo veintiuno editores, 2002), pp. 157-164 and Luciano Alonso, "Las violencias de estado durante la última dictadura argentina: problemas de definición y análisis sociohistórico," in América Latina tiempos de violencia eds. Waldo Ansaldi and Verónica Giordano (Buenos Aires, Argentina: Ariel, 2014) pp. 191-213.

${ }^{16}$ Barbara Harff, "Detection: The History and Politics of Early Warning," in Responding to Genocide. The Politics of International Action eds. Adam Lupel and Ernesto Verdeja (Boulder, CO: Lynne Rienner Publishers, 2013), p. 91.

${ }^{17}$ Adam Jones, The Scourge of Genocide. Essays and Reflections. (New York: Routledge, 2013), p. 64.

${ }^{18}$ Ernesto Verdeja, "Genocide: Debating Definitions," in Responding to Genocide: The Politics of International Action eds. Adam Lupel and Ernesto Verdeja (Boulder, CO: Lynne Rienner Publishers, 2013,) pp. 21-46.

${ }^{19}$ Daniel Feierstein, Juicios. Sobre la elaboración del genocidio II (Buenos Aires, Argentina: Fondo de Cultura Económica, 2015).

${ }^{20}$ Group mail of Feierstein entitled "Cambodia ECCC and Argentina" on March 28, 2013. Permission granted to textual quote by mail to author on 06.01.2015.

${ }^{21}$ We stated that the U.S. support to the military regimes in South America had also facilitated the first Neoliberal experiments of the free-market reforms; yet, in this study, 
and in our efforts to analyze the nature and reach of this support, we focus exclusively on the direct use of violence.

${ }^{22}$ Odd Arne Westad, The Global Cold War. Third World Interventions and the Making of Our Time (New York: Cambridge University Press, 2007), p. 3.

${ }^{23}$ Stephen G. Rabe, The Killing Zone. The United States Wages Cold War in Latin America (New York: Oxford University Press, 2012), p. 24.

${ }^{24}$ Hal Brands, Latin America's Cold War (Cambridge, MA: Harvard University Press, 2012), p. 14.

${ }^{25}$ Idem., p. 15.

${ }^{26}$ Graig Grandin, The Last Colonial Massacre. Latin America in the Cold War (Chicago, IL: The University of Chicago Press, 2004 [Kindle DX version]. Retrieved from Amazon.com) pos. 242 of 7179.

${ }^{27}$ S. G. Rabe, Op. Cit., p. 36-58.

${ }^{28}$ Roberto Russell, "La Argentina del Segundo Centenario: ficciones y realidades de la política exterior" in Argentina 1910-2010. Balance del siglo ed. Roberto Russell (Buenos Aires, Argentina: Taurus, 210) p. 238.

${ }^{29}$ Idem., p. 252

${ }^{30}$ Donald C. Hodges, Argentina's "Dirty War" An Intellectual Biography (Austin, TX: University of Texas Press, 1991), p. 11.

${ }^{31}$ Joseph Tulchin, La Argentina y Estados Unidos. Historia de una desconfianza (Buenos Aires, Argentina: Planeta, 1990), p. 154.

${ }^{32} \underline{\text { Idem}}_{\text {, p. }} 207$.

${ }^{33}$ Idem., p. 221.

${ }^{34}$ Idem., pp. 227-228.

${ }^{35}$ The complete text of the discourse is on the Web at: https://cdn.educ.ar/repositorio/Download/file?file id=2128ad00-e9ec-4460-9d948cc381a137b2 Last access on 02.05.2017.

${ }^{36}$ D. C. Hodges, Op. Cit., p. 23.

${ }^{37}$ Idem., p. 27.

${ }^{38}$ Robert A. Potash, El ejército y la política en la Argentina 1928-1945. De Yrigoyen a Perón, translation: Aníbal Leal (Buenos Aires, Argentina: Editorial Sudamericana, 1994).

${ }^{39}$ Alain Rouquié, Poder militar y sociedad política en la Argentina II. 1943-1973, translation: Arturo Iglesias Echegaray (Buenos Aires, Argentina: Emecé, 1982). 
${ }^{40}$ David Pion-Berlin, Through Corridors of Power: Institutions and Civil-Military Relations in Argentina (University Park, PA: Pennsylvania State University Press, 2010).

${ }^{41}$ R. A, Potash, Op. Cit., p. 18.

${ }^{42}$ Idem., p. 19.

${ }^{43}$ David Rock, La Argentina Autoritaria. Los nacionalistas, su historia y su influencia en la vida pública, translation: Jorge Luis Ossona (Buenos Aires, Argentina: Ariel, 1993), p. 137.

${ }^{44}$ José Paradiso, Debates y trayectoria de la política exterior argentina (Buenos Aires, Argentina: Grupo Editor Latinoamericano, 1993), p. 139.

45 J. Tulchin, Op. Cit., p. 231.

${ }^{46}$ A. Rouquié, Op. Cit., p. 131.

${ }^{47}$ Idem., p. 213.

${ }^{48}$ J. Tulchin, Op. Cit., p. 235.

${ }^{49}$ Douglas Porch, "French Imperial Warfare 1945-1962," in Counterinsurgency in Modern warfare eds. Daniel Marston and Carter Malkasian (New York: Osprey Publishing, 2008), pp. 91-112.

${ }^{50}$ In fact, the French warfare methods were first exposed in Gillo Pontecorvo's 1966 Algerian-Italian movie, The Battle of Algiers, which, besides winning several international prizes, was shown in Argentina in the 1960s as one of the interviewers in Robin's book, testifies. It is worth mentioning that the movie was shown in 2003 in the Pentagon right before the U.S. military intervention in Iraq.

${ }^{51}$ M.-M. Robin, Op. Cit., p. 296.

${ }^{52}$ Idem., p. 297.

${ }^{53}$ We borrowed the concept from Gilbert M. Joseph and Daniela Spencer, eds., 2008. In from the Cold. Latin America's New Encounter with the Cold War (Durham, NC: Duke University Press, 2008), Part II [Kindle DX version]. Retrieved from Amazon.com.

${ }^{54}$ Marisa Gallego, Teresa Eggers-Brass, Fernanda Gil Lozano, $\underline{\text { Historia }}$ Latinoamericana 1700-2005. Sociedades, culturas, procesos políticos y económicos (Buenos Aires Argentina: Editorial Maipue, 2006).

${ }^{55}$ Frederick H. Gareau, State Terrorism and the United States From

Counterinsurgency to the War on Terrorism (Atlanta, GA: Zed Books [Kindle DX version]. Retrieved from Amazon.com, 2004). Loc. 342 of 4620.

${ }^{56}$ Idem., loc. 1905 of 4620.

${ }^{57}$ Stella Calloni, Los años del lobo. Operación Cóndor (Buenos Aires, Argentina: Ediciones Continente S.R.L. 1999), p. 22. 
${ }^{58}$ Idem., p. 23.

${ }^{59}$ Sergio Buffano, 2015. "Los groupos armados no supimos escuchar el llamado a la paz de la sociedad." Interview with Astrid Pikielny, La Nación suplemento Enfoques, June 14, 2015, p. 3.

${ }^{60}$ Darío Pignotti, "Primer vuelo del Cóndor," Página/12, August 11, 2013 p. 24.

${ }^{61}$ Jorge Elías, "El abecé de la Operación Cóndor,” La Nación, October 21, 2001. On the Web at: https://www.lanacion.com.ar/210551-el-abece-de-la-operacion-condor Last access: 06.10.2015.

${ }^{62}$ S, Calloni, Op. Cit., p. 17.

${ }^{63}$ Patrice McSherry, "Tracking the Origins of a State Terror Network: Operation Cóndor," Latin American Perspectives, Vol. 29, N. 1, January, 2002, p. 40.

${ }^{64}$ Mark Atwood Lawrence, "History from Below: The United States and Latin America in the Nixon Years," in Nixon in the World. American Foreign Relations, 19691977, eds. Fredrik Logevall and Andrew Preston (New York: Oxford University Press, 2008), p. 269.

${ }^{65}$ S. G. Rabe, Op. Cit., pp. 120-122.

${ }^{66}$ Matias Spektor, Kissinger e o Brasil (Rio de Janeiro, Brazil: Zahar, 2009).

${ }^{67}$ S. G. Rabe, Op. Cit., pp 122-143.

${ }^{68}$ H. Brands, Op. Cit., p. 115.

${ }^{69}$ The complete texts of the primary documents we used for this research are found on the U.S. State Department's site at: https://foia.state.gov/ (last access on 05.20.2015) with their title and date that will be cited as a source along this article.

${ }^{70}$ Quoting Schmidli, "U.S. military assistance and training over the course of the 1960s significantly enhanced the Argentine military's repressive capacity against perceived subversives and facilitated the development of a distinctly Argentine doctrine of national security. In a 1967 Argentine Intelligence School guide on countersubversion, for example, U.S. military manuals and course materials constituted nearly one-third of the sources cited. Likewise, by the end of the 1960s, dozens of federal police officers and nearly four thousand military officers had been trained at U.S. facilities in the Canal Zone or in the continental United States, and between 1963 and 1967, the United States supplied Argentina with $\$ 60$ million worth of arms and equipment through grant and sales agreements." (William Michael Schmidli, 2013. The Fate of Freedom Elswhere. Human Rights and U.S. Cold War Policy Toward Argentina (New York: Cornell University Press, 2013), 42)

${ }^{71}$ U.S. Embassy info 1042, "Military Take Cognizance of Human Rights Issue," February 16, 1976. 
72 Telegram 1751, U.S. Embassy, “Ambassador’s Conversation with Admiral Massera," March 16, 1976.

${ }^{73}$ Telegram 1896, U.S. Embassy, “Terrorist Toll Continues High,” March 22, 1976.

${ }^{74}$ Telegram 2061, U.S. Embassy, "Videla’s Moderate Line Privails,,” March 29, 1976.

${ }^{75}$ Cable 02528, U.S. Embassy, "Junta Record on Human Rights to Date," April 16, 1976, p. 6.

${ }^{76}$ William Michael Schmidli, The Fate of Freedom Elswhere. Human Rights and U.S. Cold War Policy Toward Argentina (New York: Cornell University Press, 2013), p. 49.

${ }^{77}$ Idem., p. 50.

${ }^{78}$ Telegram 3142, U.S. Embassy, “Junta’s Moderate Line in Doubt,” May 11, 1976, p. 1.

${ }^{79}$ Carlos Osorio and Kathleen Costar, eds., "If There Are Things That Have to Be Done, You Should Do Them Quickly" National Security Archive Electronic Briefing Book No. 133, posted on August 27, 2004. On the Web at: http://nsarchive.gwu.edu/NSAEBB/NSAEBB133/index.htm Last access on 05.20.2015.

${ }^{80}$ W. M. Schmidli, Op. Cit., p. 53.

${ }^{81}$ Idem., p. 84.

${ }^{82}$ Alejandro Avenburg, "Entre la presión y el apoyo a los "moderados." La política de derechos humanos de Carter y el régimen militar argentino (1976-1978)," Unpublished Graduate Thesis. Maestría en Relaciones y Negociaciones Internacionales, FLACSO/Argentina-Universidad de San Andrés en cooperación con la Universidad de Barcelona, 2009, p. 46.

${ }^{83}$ Walter Goobar and Francisco Bálasz, "La solidaridad y valentía de un diplomático yanqui," interview to Tex Harris, Miradas al Sur, March 25, 2012, p. 4.

${ }^{84} \underline{\text { Idem. }}$

${ }^{85}$ Idem,, p. 7.

${ }^{86}$ W. M. Schmidli, Op. Cit., pp. 144-147.

${ }^{87}$ Martín Granovsky, “De Todman a los buitres,” Página/12, August 17, 2014, p. 6.

${ }^{88}$ W. M. Schmidli, Op. Cit., pp. 163-164.

${ }^{89}$ Idem., pp. 180-181.

${ }^{90}$ J. Tulchin, Op. Cit., p. 249. 
Journal: GSI; Volume 11; Issue: 2

DOI: $10.3138 / \mathrm{gsi} .11 .2 .03$

${ }^{91}$ Ariel C. Armouny, La Argentina, los Estados Unidos y la cruzada anticomunista en América Central, 1977-1984 (Buenos Aires, Argentina: Universidad Nacional de Quilmes, 1999) pp. 121-167. 